\title{
PEMBERDAYAAN MASYARAKAT DALAM PENINGKATAN NILAI TAMBAH PENGOLAHAN LIMBAH KULIT PISANG (MUSA PARADISIACA) MENJADI TEPUNG UNTUK MENINGKATKAN PENDAPATAN MASYARAKAT
}

\author{
Yuszda K. Salimi ${ }^{*}$, Citron S. Payu ${ }^{1}$ \\ Program Studi Fisika, Fakultas Matematika dan Ilmu Pengetahuan Alam, Universitas Negeri Gorontalo, \\ Gorontalo, Indonesia \\ *Penulis Korespondensi: yuszdaksalimi@ung.ac.id
}

\begin{abstract}
Abstrak
Progam KKN PPM Desa Barakati Kecamatan Batudaa Kabupaten Gorontalo dilaksanakan dengan tujuan meningkatkan pendapatan masyarakat melalui pengolahan limbah Kulit Pisang. Upaya yang dilakukan adalah melalui pengolahan Kulit Pisang menjadi Tepung yang berkualitas serta memiliki nilai jual yang berkompeten dipasaran. Adapun metode yang digunakan dalam program ini adalah metode penyuluhan, pelatihan, teori dan praktek. Program ini bekerja sama dengan kelompok masyarakat UP. FMA Desa Barakati sebagai mitra dalam pusat pengolahan Kulit Pisang menjadi Tepung. Alur kegiatan meliputi tahap persiapan berupa observasi ke dinas instansi terkait dan pembekalan mahasiswa KKNPPM. Kemudian tahap pelaksanaan, yaitu penyuluhan dan pelatihan pada masyarakat di 4 dusun yakni Dusun I Hungayo, Dusun II Botuhuwayo, Dusun III Hutamela dan Dusun IV Bontula, yang berpusat di UP-FMA Desa Barakati. Adapun diantara hasil yang telah dicapai adalah 1) meingkatnya pengetahuan dan keterampilan kelompok masyarakat sasaran dalam pengolahan limbah kulit pisang, 2) meningkatnya pendapatan kelompok sasaran sebagai akibat dari penjualan hasil produksi, 3) Mengurangi tingkat pengangguran di tingkat desa. Oleh karena itu program ini telah memberikan dampak positif bagi kelompok masyarakat sebagai sasaran, pemerintah desa setempat, tim dosen pelaksana dan mahasiswa peserta KKN PPM Tahun 2019.
\end{abstract}

Kata Kunci : Pemberdayaan, Pengolahan, Kulit Pisang.

\begin{abstract}
The community service at Barakati Village, Batudaa Sub-district, Gorontalo District is conducted to improve the community's income through the processing of banana peel waste. The effort made is through the processing of banana peel into a quality and high selling flour. The methods used are counseling, training, theory, and practice. This program cooperates with a community group of UP. FMA Barakati village as a partner in the center of banana peel processing into flour. The flow of activities includes a preparation phase in the form of observation to the related institutions and students' Community Service Program briefing. The next phase is implementation which is counseling and training to the community at 4 orchards; Orchard I Hungayo, Orchard II Botuhuwayu, Orchard III Hutamela and Orchard IV Bontula which centered on UP-FMA Barakati Village. The achieved results, among others, are: 1) the increase of knowledge and skill of targeted community group in processing banana peel waste, 2) the increase of targeted community's income as a result of product sales, 3) decrease the level of unemployment within the village. Therefore, this program has shown a positive impact on the targeted community group, the local village government, the team of implementing lecturers and students who are participants of the community service program 2019.
\end{abstract}

Keywords : Empowerment, Processing, Banana Peel.

\section{PENDAHULUAN}

Desa Barakati merupakan salah satu Desa dari 8 Desa yang berada di kecamatan Batudaa yang berdasarkan letak geografis berada disebelah barat dari Desa Iluta dengan luas 346 Ha. Dengan kondisi Tofografi alam Desa Barakati, sebagaimana di desa-desa lain mempunyai iklim kemarau dan penghujan.Desa Barakati terbagi dalam 4 Dusun yaitu Dusun Hungayo,
Dusun Botuhuwayo, Dusun Hutamela, dan Dusun Bontula. Pada aspek demografis, pada tahun 2014 Desa Barakati memiliki penduduk sejumlah 2278 jiwa, tahun tahun 2015 sejumlah 2295 dan tahun 2016 sejumlah 2314. 


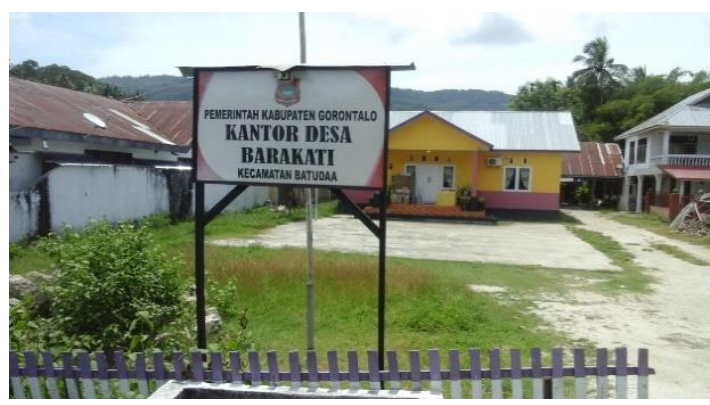

Gambar 1. Kantor Desa Barakati.

Keadaan perekonomian di Desa Barakati lebih didominasi oleh sektor pertanian dan nelayan. Dari data yang ada lahan pertanian yang ada di desa ini adalah seluas 77.50 Ha diwilayah dusun Hungayo, Dusun Botuhuwayo, Dusun Botuhuwayo, Dusun Hutamela dan Dusun Bontula dan lahan nelayan seluas $3 \mathrm{Ha}$ di wilayah Dusun Hungayo. Dari sektor pertanian terdapat banyak komoditi yang memiliki tingkat hasil panen yang cukup besar, atau sangat berpotensi. Salah satu komoditas yang dominan dari sektor pertanian di Desa ini adalah dari tanaman buah pisang. Pisang merupakan tanaman asli Asia Tenggara (termasuk Indonesia), Afrika (Madagaskar), Amerika Selatan dan Amerika Tengah, yang banyak ditemukan hidup berkelompok di daerah tropis maupun subtropis dan dapat tumbuh baik di daratan tinggi dan rendah. Pisang juga merupakan tanaman buah berupa herba dengan nama latinnya adalah Musa Paradisiaca. Di Gorontalo, dikenal dengan sebutan Lutu atau Lambi. Volume produksi buah pisang di Indonesia sangat besar, khususnya di Kabupaten Gorontalo menurut Badan Pusat Statistik (BPS) Provinsi Gorontalo bahwa ada sekitar 13,827 kuintal buah pisang pada tahun 2015 .

Pada tanaman pisang, bukan buah pisangnya saja yang memiliki manfaat dan mengandung gizi yang tinggi, tetapi bagian lain dari tanaman pisang juga memiliki manfaat, contohnya adalah Kulit Pisang. Berdasarkan informasi yang diberikan oleh Pusat Penganekaragaman Konsumsi dan Keamanan Pangan, Badan Ketahanan Pangan Kementerian Pertanian Republik Indonesia, bahwa Kulit Pisang mengandung vitamin C, vitamin B, kalsium, protein, dan juga lemak yang cukup.

Menurut Balai Penelitian dan Pengembangan Industri, Jatim, Surabaya (1982), komposisi zat gizi yang terkandung dalam Kulit Pisang (per 100 gram bahan), dapat dilihat pada Tabel 1 berikut ini:

Tabel 1. Zat Gizi pada Kulit Pisang.

\begin{tabular}{|c|l|c|}
\hline No & \multicolumn{1}{|c|}{ Zat Gizi } & Kadar \\
\hline 1 & Air $(\mathrm{g})$ & 68,90 \\
\hline 2 & Karbohidrat $(\mathrm{g})$ & 18,50 \\
\hline 3 & Lemak $(\mathrm{g})$ & 2,11 \\
\hline 4 & Protein $(\mathrm{g})$ & 0,32 \\
\hline 5 & Kalsium $(\mathrm{mg})$ & 715 \\
\hline
\end{tabular}

\begin{tabular}{|c|l|c|}
\hline 6 & Fosfor (mg) & 117 \\
\hline 7 & Zat Besi (mg) & 1,60 \\
\hline 8 & Vitamin B (mg) & 0,12 \\
\hline 9 & Vitamin C (mg) & 17,50 \\
\hline
\end{tabular}

Sumber : Balai Penelitian dan Pengembangan Industri, Jatim, Surabaya (1982).

Karbohidrat yang dikandung oleh kulit pisang adalah amilum. Amilum atau pati ialah jenis polisakarida karbohidrat (karbohidrat kompleks). Amilum (pati) tidak larut dalam air, berwujud bubuk putih, tawar dan tidak berbau. Pati merupakan bahan utama yang dihasilkan oleh tumbuhan untuk menyimpan kelebihan glukosa (sebagai produk fotosintesis) dalam jangka panjang. Hewan dan manusia juga menjadikan pati sebagai sumber energi yang penting. Amilum merupakan sumber energi utama bagi orang dewasa di seluruh penduduk dunia, terutama di negara berkembang oleh karena di konsumsi sebagai bahan makanan pokok. Disamping bahan pangan kaya akan amilum juga mengandung protein, vitamin, serat dan beberapa zat gizi penting lainnya (Johari dan Rahmawati, 2006).

Desa Barakati merupakan salah satu daerah yang memiliki potensi tanaman Pisang seperti yang diungkapkan oleh salah satu petani yang memiliki lahan tanaman pisang di Desa Barakati, Bapak Sudirman Katili mengatakan bahwa produksi Buah Pisang dalam sekali panen di lahan pertanian beliau yang seluas 1 hektar adalah sekitar30 ton. Di Gorontalo, khususnya di Desa Barakati, Kulit Pisang masih sangat jarang dimanfaatkan kecuali untuk makanan ternak seperti sapi dan kambing bahkan cenderung menjadi bahan buangan (limbah), padahal jumlahnya cukup banyak. Menurut Basse (2000) jumlah dari kulit pisang cukup banyak, yaitu kira- kira $1 / 3$ dari buah pisang yang belum dikupas.

Hal ini mungkin dikarenakan, para peminat Buah Pisang, yang hanya memanfaatkan buahnya saja, sementara Kulit Pisangnya dibuang begitu saja, Begitupun dengan para penjual Buah Pisang, ketika Pisangnya yang tidak laku dipasaran, maka mereka hanya mengolah pisangnya menjadi makanan siap saji atau makanan ringan (cemilan), sedangkan kulitnya dibuang atau diberi makan ternak.

Dari uraian diatas, terlihat bahwa masalah utamanya yaitu terdapat pada tingkat pengolahan limbah kulit pisang yang masih rendah. Hal ini dikarenakan para Petani maupun Peminat Pisang, hanya memanfaatkan Buah Pisangnya saja, sementara mereka tidak memiliki ide atau kemampuan mengelolah Kulit Pisang sehingga tidak terbuang sia-sia. Adapun solusi yang ditawarkan adalah dengan mengolah Kulit Pisang menjadi Tepung, yang tentunya memiliki daya jual yang tinggi di pasaran. Tepung merupakan salah satu bentuk alternatif produk setengah jadi yang dianjurkan, karena lebih tahan 
disimpan, mudah dicampur (dibuat komposit), diperkaya zat gizi (difortifikasi), dibentuk, dan lebih cepat dimasak sesuai tuntutan kehidupan modern yang serba praktis.

Prosedur pembuatan tepung sangat beragam, dibedakan berdasarkan sifat dan komponen kimia bahan pangan. Namun, secara garis besar dapat dikelompokkan menjadi dua yaitu pertama bahan pangan yang mudah menjadi coklat apabila dikupas dan kedua bahan pangan yang tidak mudah menjadi coklat. Secara umum, umbiumbian dan buah-buahan mudah mengalami pencoklatan setelah dikupas. Hal ini disebabkan oksidasi dengan udara sehingga terbentuk reaksi pencoklatan oleh pengaruh enzim yang terdapat dalam bahan pangan tersebut (browning enzymatic). Pencoklatan karena enzim merupakan reaksi antara oksigen dan suatu senyawa phenol yang dikatalisis oleh polyphenol oksidase.

Untuk menghindari terbentuknya warna coklat pada bahan pangan yang akan dibuat tepung dapat dilakukan dengan mencegah sesedikit mungkin kontak antara bahan yang telah dikupas dan udara dengan cara merendam dalam air (atau larutan garam 1\% dan atau menginaktifkan enzim dalam proses blansir) (Widowati dan Damardjati, 2000). Kebutuhan akan Tepung merupakan salah satu kebutuhan utama yang harus disiapkan dalam pembuatan kue.Ketersediaan Tepung dipasaran, terkadang tidak sesuai kebutuhan terutama pada bulan-bulan tertentu seperti pada bulan Ramadhan menjelang hari lebaran idul fitri, dimana Tepung yang dijual dipasaran cepat habis walaupun harganya mahal, dengan kata lain, tidak seimbang antara banyakya Tepung yang dijual dengan kebutuhan konsumen akan Tepung tersebut. Hal ini sesuai dengan hasil wawancara dengan beberapa Ibu Rumah Tangga. Sehingga, sebagai solusi bahwa dengan adanya pengolahan Kulit Pisang sebagai Tepung diharapkan dapat menjawab permasalahan ini juga.

Pengolahan Kulit Pisang menjadi Tepung ini di Sosialisasikan melalui Kegiatan Kuliah Kerja Nyata Pembelajaran dan Pemberdayaan Masyarakat (KKNPPM) oleh Lembaga Penelitian dan Pengabdian Masyarakat (LPPM)Universitas Negeri Gorontalo (UNG). Kegiatan ini berupa Penyuluhan dan Pelatihan pembuatan Tepung oleh Dosen dan Mahasiswa UNG terhadap masyarakat Desa Barakati. Adanya partisipasi langsung masyarakat ini diharapkan dapat mengembangkan pengolahan Kulit Pisang sehingga kegiatan ini dapat berkelanjutan. Dalam pelaksanaan kegiatan yang diusulkan ini, yang menjadi Mitra dalam kegiatan ini adalah UP-FMA Desa BarakatiKecamatan Batudaa Kabupaten Gorontalo. Adapun profil singkat UP-FMA Desa Barakati : UP-FMA Desa Barakati adalah Kelompok sosial masyarakat yang berkenaan dengan segala aktivitas pengolahan hasil pertanian di desa Barakati (FMA =Farmer Management Activity). UP. FMA Barakati terbentuk pada tanggal 30 Desember
2007 sesuai dengan Berita Acara Pembentukan FMA No. 140/DS.BRKT/458.

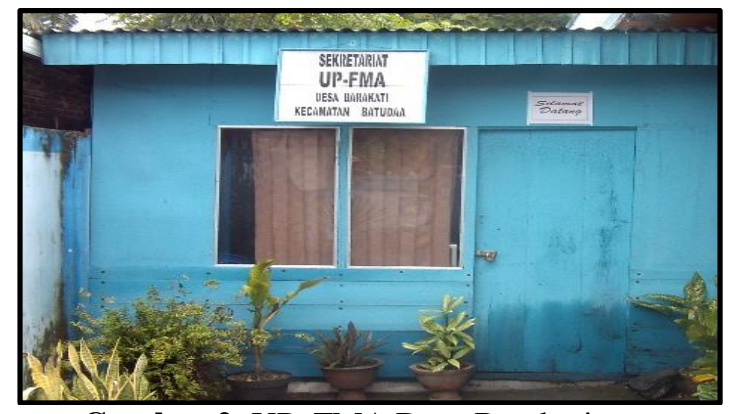

Gambar 2. UP. FMA Desa Barakati.

Visi dari UP. FMA Barakati adalah tercapainya peningkatan pendapatan petani melalui kegiatan yang dikelola oleh petani. Sedangkan Misi dari UP. FMA Barakati adalah : 1) Memberdayakan SDM dan SDA yang dimiliki desa Barakati secara terpadu dan terarah, 2) Mendorong peran serta sumber daya kelembagaan petani sebagai pelaku utama dan pelaku usaha dalam proses percepatan peningkatan pendapatan petani, 3) Meningkatkan kapasitas dan kualifikasi serta keterampilan keluarga petani melalui program pemberdayaan petani melalui teknologi dan informasi pertanian, 4) Menyusun strategi penyuluhan yang dikelola petani secara berkelanjutan dan dilakukan melalui pendekatan pembangunan secara terpadu dan berkesinambungan

Bantuan yang diberikan mitra dalam hal ini berupa penyediaan Gedung Lokasi sosialisasi dan pelatihan di desa Barakati. Program ini juga didukung oleh aparatur pemerintah desa Barakati, sebagai perangkat penting sebagai pendukung segala urusan administratif di lokasi Pengabdian. Adapun kelompok sasaran dalam kegiatan ini adalah masyarakat petani Tanaman Pisang, para penjual Buah Pisang dan masyarakat Peminat (konsumen) Buah Pisang.

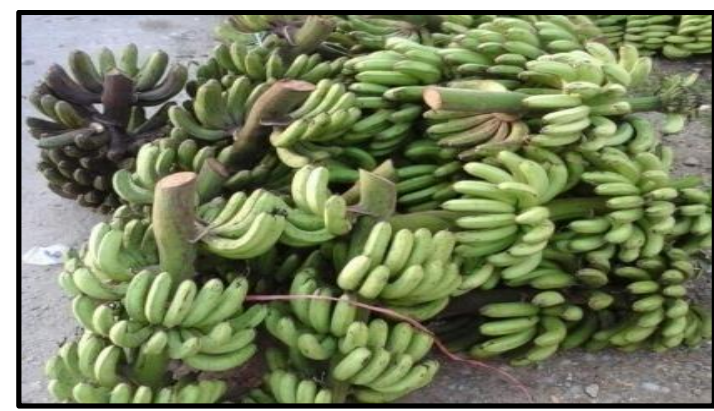

Gambar 3. Hasil panen buah pisang.

Melalui Observasi lapangan, rata-rata Masyarakat Petani Tanaman Pisang memiliki kondisi perekonomian yang tergolong cukup rendah. Melalui kegiatan ini, diharapkan dapat mendongkrak ekonomi Masyarakat Petani melalui pengolahan Kulit Pisang menjadi Tepung yang akan dipasarkan baik melalui pasar tradisional maupun toko-toko yang berada di Provinsi Gorontalo. Kegiatan yang akan dilaksanakan ini, tentunya memiliki 
target dan luaran yang harus dicapai setelah kegiatan ini selesai dilaksanakan. Target dari pelaksanaan kegiatan Pemberdayaan Ekonomi Masyarakat Petani melalui Pengolahan Bahan Baku Kulit Pisang menjadi Produk Tepung di Desa Barakati Kecamatan Batudaa Kabupaten Gorontalo. Dengan mendapatkan pelatihan proses pembuatan tersebut diharapkan masyarakat dapat mengembangkan pemanfaatan Kulit Pisang dan meningkatkan pendapatan masyarakat, khususnya petani tanaman pisang di desa Barakati.

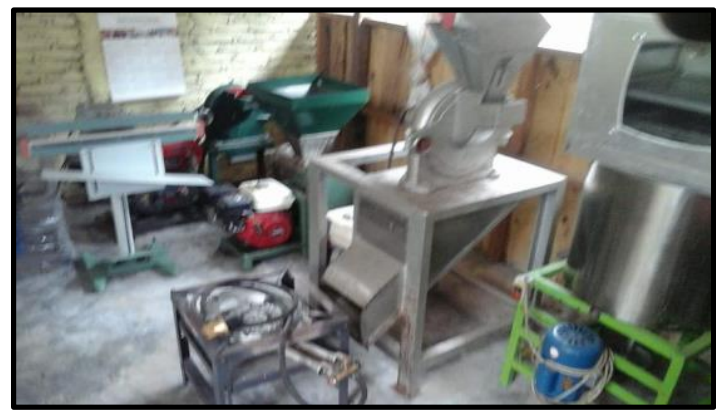

Gambar 4. Mesin Produksi/Pengolahan.

\section{BAHAN DAN METODE}

Persiapan Pembuatan Tepung yang terdiri dari bahan pembuatan tepung : 1) Pisang Raja, 2) Air, 3) Natrium Tiosulfat. Alat yang diperlukan : 1) Pisau atau Alat Pengiris, 2) Alat Penggiling (Hammer Mill), 3) Alat Pengering Gabah, jika ada, 4)Ayakan atau Saringan, 5) Plastik Polietilen. Metode yang digunakan yaitu metode observasi partisipatif terhadap objek dimana penulis mengamati dan terlibat langsung dalam setiap langkah kerjanya. Di samping itu dilakukan wawancara dengan pembimbing lapangan serta karyawan yang bekerja dilokasi pengamatan. Wawancara dilakukan kepada sumber yang memilki kapasitas untuk memberikan jawaban mengenai proses pembuatan Tepung yang berbahan baku Kulit Pisang yang dilakukan di UPFMA Desa Barakati dengan tujuan menggali informasi secara tepat dan akurat.

\section{HASIL DAN PEMBAHASAN}

Langkah-langkah dalam bentuk program yang akan dilaksanakan adalah program produksi pembuatan Tepung. Metode yang digunakan dalam melakukan pemberdayaan kelompok sasaran adalah pembelajaran teknik membuat Tepung yang berkualitas disertai teori dan praktek langsung. Pembelajaran disertai praktek akan dilakukan oleh mahasiswa bersama-sama dengan kelompok sasaran yang juga didampingi oleh mitra yang professional di bidangnya.

Disamping itu pula tim pelaksana menyelenggarakan kegiatan inti dalam bentuk bimbingan teknis pengolahan kulit pisang menjadi produk tepung yang sehat dan higienis ciri khas desa Barakati, dengan materi sebagai berikut:

1. Materi Pertama: Potensi limbah kulit pisang dan Berbagai Permasalahan yang dihadapi kelompok sasaran. Dalam materi ini banyak mengulas tentang bagaimana merubah sampah kulit pisang tidak terpakai menjadi olahan tepung yang sehat dan higienis. Terus meningkatnya kulit pisang di wilayah ini menjadi fokus perhatian sendiri yang harus diupayakan pemanfaatannya. Materi ini memotivasi kelompok sasaran dalam mengidentifikasi jenis dan jumlah kulit pisang untuk diproduksi menjadi tepung yang selanjutnya dapat dikonsumsi oleh rumah tangga, dipasarkan di desa tetangga dan dipasarkan melalui mitra kegiatan pengabdian KKN PPM. Hasilnya menunjukkan $80 \%$ peserta tertarik, memahami dan bersedia mengimplementasikan pengolahan kulit pisang menjadi tepung.

2. Materi Kedua: Sinergi Pemeritah dan Perguruan Tinggi Serta Masyarakat Dalam Upaya Pemberdayaan dan Peningkatan Kesejahteraan Kelompok Petani dan pengolah kulit pisang menjadi tepung. Pada bagian ini difokuskan pada pentingnya exploitasi potensi dan sumberdaya alam di desa yang bermitra dengan stakeholders. Dalam hal ini peran perguruan tinggi adalah bagaimana menerapkan ilmu pengetahuan dan teknologi untuk menyelesaikan berbagai masalah yang dihadapi kelompok masyarakat sebagai sasaran. Hasilnya menunjukkan $90 \%$ peserta memahami dan bersedia mengikuti program pemberdayaan yang bermitra dengan perguruan tinggi. Oleh karena itu sinergi kemitraan pada masa yang akan datang akan terus dilanjutkan melalui implementasi berbagai program pentingny lainnya.

3. Materi Ketiga: Tata kelola manajemen dan Penataan Kelembagaan Kelompok. Dalam materi ini ditegaskan tentang pentingnya pemahaman terhadap fungsi-fungsi manajemen dan unsure-unsur manajemen, serta bagaimana pula perpaduan antara keduanya. Pentingnya pemahaan dan praktek manajemen menjadi kunci utama dalam suksesnya pengelolaan usaha. Hasilnya menunjukkan $85 \%$ peserta memahami konsep dan bersedia menerapkan iptek tersebut untuk memperoleh manfaat pada a) meningkatnya pengetahuan kelompok sasaran, b) meningkatnya keterampilan, c) efektifnya tata kelola usaha kelompok, d) pencapaian target usaha kelompok.

4. Materi Keempat: Pentingnya Aspek Hukum Dalam Bisnis. Materi ini menegaskan akan pentingnya mempertimbangkan aspek hukum dalam bisnis melalui tindakan-tindakan yang tidak bertentangan dengan hukum baik secara pidana maupun perdata. Secara pidana yang harus diperhatikan misalnya tentang jaminan kandungan produk makanan yang tidak mengandung bahan berbahaya yang dapat berakibat pada gangguan kesehatan hingga kematian pada konsumen. Sedangkan secara perdata misalnya tentang pentingnya penggunaan merk dagang secara mandiri tanpa melalui duplikasi dari produk lain. Hasilnya menunjukkan $80 \%$ peserta memahami pentingnya aspek hukum dalam bisnis, untuk 
mengikuti semua ketentuan yang berlaku dalam tata kelola usaha.

5. Materi Kelima: Aspek Manajemen Usaha. Materi ini menegaskan akan pentingnya manajemen usaha yang profesional dalam operasional bisnis. Manajemen sebagai kunci kesuksesan bisnis dilakukan melalui praktek fungsi-fungsi manajemen yang meliputi: perencanaan, pengorganisasian, pelaksanaan, pemasaran dan evaluasi untuk keberlanjutan usaha. Disamping fungsi manajemen dibahas pula dalam materi ini menyangkut unsurunsur manajemen yang meliputi: manusia (man), bahan (material), mesin (machine), uang (money) dan pasar (market). Kombinasi antara fungsi manajemen dan unsur manajemen menghasilkan efektifitas dan efisiensi manajemen bisnis yang berkelanjutan. Hasilnya menunjukkan: $90 \%$ kelompok masyarakat sebagai sasaran memperoleh pengetahuan baru tentang manajemen bisnis pengolahan kulit pisang sebagai produk tepung yang sehat dan higienis.

Hasil kegiatan bimbingan teknis proses pengolahan limbah kulit pisang menjadi produk tepung yang sehat dan higienis di Desa Barakati memberikan pengalaman dan penguatan terhadap anggota kelompok pengrajin akan potensi bisnis yang dihasilkan dari pemanfaatan limbah kulit pisang yang banyak ditemui dilokasi. Disamping itu pula bimbingan teknis memberikan bekal pengetahuan manajemen pengolahan usaha beserta implementasinya pada kegiatan usaha. Hal penting lainnya dari bimbingan teknis adalah pengetahuan bagi kelompok usaha juga diberikan mengenai aspek hukum dalam usaha. Hal tersebut untuk memberikan jaminan kepastian hukum maupun legalitas terhadap usaha yang dijalankan, juga untuk memberikan pengetahuan tentang berbagai resiko yang mungkin saja terjadi dalam bisnis. Disamping itu pula peserta sebagai kelompok sasaran dibekali tentang kemitraan dengan pihak usaha lain, perencanaan pasar dan sebagainya. Kegiatan bimbingan teknis dilanjutkan pula dengan teori dan praktek penyusunan rencana binis bagi sektor usaha kecil menengah yang diikuti oleh seluruh peserta anggota kelompok.

\section{KESIMPULAN}

Hasil implementasi program KKN-PPM di Desa Barakati tahun 2019 mampu memberikan dampak positif bagi tim dosen pelaksana, mahasiswa dan utamaya bagi kelompok sasaran. Berbagai manfaat tersebut setidaknya dapat diuraikan sebagai berikut:

1) Pengolahan kulit pisang menjadi tepung higienis memiliki potensi untuk pemberdayaan ekonomi masyarakat desa.

2) Masyarakat selaku kelompok sasaran mampu memahami materi bimtek dan proses pengolahan limbah kulit pisang menjadi tepung higienis.

3) Program KKN PPM melalui pengolahan kulit pisang menjadi tepung telah dilaksanakan melalui prosedur ilmiah penerapan iptek bagi kelompok masyarakat sebagai sasaran.

Berdasarkan implementasi dan hasil akhir kegiatan maka tim pelaksana mengusulkan beberapa aspek sebagai berikut:

1) Program KKN-PPM yang telah dilaksanakan sebaiknya dilanjutkan dengan intervensi programprogram berbasis kemasyarakatan lainnya.

2) Program KKN-PPM perlu difokuskan pada masalah empirik lainnya, khususnya pada aspek peningkatan produksi dan perluasan pemasaran.

3) Keberlanjutan program KKN PPM perlu didukung oleh stakeholders terkait dengan mengangkat berbagai potensi unggulan di desa.

\section{UCAPAN TERIMAKASIH}

Dengan suksesnya implementasi program KKN-PPM Desa Barakati Tahun 2019 maka hasil kegiatan ini telah memberikan manfaat bagi kelompok sasaran. Oleh karena itu pada kesempatan ini kami menyampaikan ucapan terimakasih disampaikan kepada 1) Direktorat jenderal pengabdian masyarakat Kementerian Ristek dan Dikti Republik Indonesia, 2) Pimpinan dan seluruh staf Lembaga Penelitian dan Pengabdian masyarakat Universitas Negeri Gorontalo, 3) Pemerintah Kabupaten Gorontalo, Kecamatan Batudaa Pantai dan pemerintah desa Barakati, 4) Kelompok pengrajin dan pengolah produk tepung di Desa Barakati, 5) Tim pelaksana dan mahasiswa peserta KKN-PPM.

\section{DAFTAR PUSTAKA}

Basse. 2000. Compost Engineering, An Arbour Science, London

Balai Penelitian dan Pengembangan Industri, Jatim, Surabaya (1982).

BPS Provinsi Gorontalo, 2015, Provinsi Gorontalo dalam angka

Johari, dan Rahmawati, 2006, Kimia SMA untuk Keas XII, Jakarta, Esis

Widowati Damarjanti, D.S, S., 2000, Potensi dan pendayagunaan Sumber daya bahan pangan local Serealia, Umbi-umbian dan kacangkacangan untuk penganekaragaman pangan, KMNRT, Jakarta 